GRASAS Y ACEITES 69 (4)

October-December 2018, e281

ISSN-L: 0017-3495

https://doi.org/10.3989/gya.0350181

\title{
Quality preservation of walnut kernels using edible coatings
}

\author{
A.L. Grosso ${ }^{a}$, C.M. Asensio ${ }^{a}$, V. Nepote ${ }^{b}$ and N.R. Grosso ${ }^{a, \bigotimes}$ \\ ${ }^{a}$ Facultad de Ciencias Agropecuarias, Universidad Nacional de Córdoba (UNC), Instituto Multidisciplinario \\ de Biología Vegetal (IMBIV), Consejo Nacional de Investigaciones Científicas y Técnicas (CONICET). \\ Ing. Agr. Félix Aldo Marrone 746, CC 509, X5016GCA, Córdoba, Argentina. \\ ${ }^{b}$ Facultad de Ciencias Exactas, Físicas y Naturales, Universidad Nacional de Córdoba (UNC), Instituto \\ Multidisciplinario de Biología Vegetal (IMBIV), Consejo Nacional de Investigaciones Científicas y Técnicas (CONICET). \\ Av. Vélez Sarsfield 1611, 5000, Córdoba, Argentina. \\ ${ }^{\square}$ Corresponding author: nrgrosso@agro.unc.edu.ar
}

Submitted: 31 March 2018; Accepted: 11 June 2018

SUMMARY: The objective of this work was to evaluate the performance of various edible coatings for preserving the quality of walnut kernels (W) during storage. Three edible coatings based on carboxymethyl cellulose (CMC), methyl cellulose (MC) and whey protein isolates (WP) were prepared. Coated and uncoated walnuts (WC) were stored for 210 days at room temperature $\left(23 \pm 2{ }^{\circ} \mathrm{C}\right)$. After 210 days, WC presented the highest peroxide value $(\mathrm{PV}=3.06 \mathrm{meqO} / \mathrm{kg})$, conjugated dienes $(\mathrm{CD}=3.01)$ and trienes $(\mathrm{CT}=0.31)$, pentanal, nonanal, hexanal, and decane, 5,6-bis (2,2-dimethylpropylidene) contents. Meanwhile, WMC showed the lowest $\mathrm{PV}(1.20 \mathrm{meqO} 2 / \mathrm{kg}), \mathrm{CD}(2.26)$ and $\mathrm{CT}(0.17)$ and the lowest decrease in carotenoid content $(0.60 \mathrm{mg} / \mathrm{kg})$. The $\mathrm{L}^{*}$ value measured in walnut oil decreased in all samples. MC, CMC and WP coatings showed protection on walnuts against the deterioration process. MC coating displayed the best performance.

KEYWORDS: Coatings; Oxidation; Preservation; Walnuts

RESUMEN: Conservación de la calidad de los granos de nueces utilizando recubrimientos comestibles. El objetivo de este trabajo fue evaluar el comportamiento de cubiertas comestibles para preservar la calidad de nueces (W). Tres tipos de cubiertas fueron estudiadas: carboximetilcelulosa (CMC), metilcelulosa (MC) y aislados proteicos de suero de leche (WP). Las nueces con y sin cobertura (WC) fueron almacenadas durante 210 días a temperatura ambiente $\left(23 \pm 2{ }^{\circ} \mathrm{C}\right)$. WC presentó los valores más altos para indicadores químicos de oxidación lipídica (índice de peróxidos $(\mathrm{PV})=3,06 \mathrm{meqO} / \mathrm{kg}$; dienos conjugados $(\mathrm{CD})=3,01$ y trienos conjugados $(\mathrm{CT})=0,31)$ y para volátiles de oxidación (pentanal, nonanal, hexanal y decane,5,6-bis(2,2-dimethylpropylidene). Por el contrario, WMC presentó los menores $\mathrm{PV}(1,20 \mathrm{meqO} 2 / \mathrm{kg}), \mathrm{CD}(2,26)$ y CT $(0,17)$ y la menor desaparición de carotenoides $(0,60 \mathrm{mg} / \mathrm{kg})$. El valor L* medido en el aceite de nuez decreció en todos los tratamientos. Las cubiertas comestibles MC, CMC y WP exhibieron efecto protector en el deterioro de las nueces. MC fue la que presentó mejor comportamiento.

PALABRAS CLAVE: Cubiertas comestibles; Nueces; Oxidación; Preservación

ORCID ID: Grosso AL https://orcid.org/0000-0003-3174-5745, Asensio CM https://orcid.org/0000-0003-0744-9188, Nepote V https://orcid.org/0000-0002-0615-5316, Grosso NR https://orcid.org/0000-0002-1709-9671

Citation/Cómo citar este artículo: Grosso AL, Asensio CM, Nepote V, Grosso NR. 2018. Quality preservation of walnut kernels using edible coatings. Grasas Aceites 69 (4), e281. https://doi.org/10.3989/gya.0350181

Copyright: (02018 CSIC. This is an open-access article distributed under the terms of the Creative Commons Attribution 4.0 International (CC BY 4.0) License. 


\section{INTRODUCTION}

The walnut (Juglans regia L.) is a crop of high economic importance for the food industry (Martínez et al., 2013). For this reason, the cultivated area is rapidly growing in many countries (Christopoulos and Tsantili, 2011). The crop is only harvested once a year, so it is very important to preserve the chemical and sensory qualities of the kernels until the next year's harvest. The most abundant chemical component of walnut kernels is the oil, which constitutes 52 to $70 \%$ of the kernel mass (Zwarts et al., 1999; Grosso et al., 2017). Walnut oil is considered unique because it presents high levels of polyunsaturated fatty acids (PUFA), with a perfect balance of $n-6$ and n-3 PUFAs. The consumption of oils containing the ideal ratio of these fatty acids (4:1) has been shown to decrease the risk of cardiovascular disease (Martínez et al., 2011). PUFAs have also been associated with other health-promoting properties. The lipid oxidation of walnuts results in losses of essential fatty acids and vitamins, the appearance of off-flavors, and the generation of toxic compounds and color changes which decrease their nutritional, sensory, chemical and economic value and limit the shelf-life of walnut kernels (Salcedo et al., 2010; Grosso et al., 2017).

Product stability depends on the preservation of quality parameters during storage and is a key issue when determining shelf-life and distribution logistics. Previous studies have demonstrated that the sensory, microbiological and chemical quality of different types of foods and their raw materials can be preserved by applying an edible coating. Edible coatings are a type of biodegradable active packaging material that can extend shelflife and enhance the functional properties of food products by improving the stability of their lipids (Gayol et al., 2009; Embuscado and Huber, 2009; Grosso et al., 2017; Riveros et al., 2018; Larrauri et al., 2016). Previous research has focused on the effect of chitosan added with green tea extract on walnuts (Sabaghi et al., 2015), soy protein isolates (Kang et al., 2012), pea starch, whey protein isolate, and carnauba wax coating (Mehyar et al., 2012) on the nut's quality. The research makes a contribution to the knowledge about the preservation of the chemical quality parameters of walnuts using commercial edible coatings for an extended period of time. The objective of this work was to evaluate the performance of various edible coatings in preserving the quality of walnut kernels during 210 days of storage at room temperature $\left(23 \pm 2{ }^{\circ} \mathrm{C}\right)$, by studying physical and chemical variables.

\section{MATERIALS AND METHODS}

\subsection{Materials}

Fresh butterfly walnut kernels (Chandler variety) harvested in April, 2016 were provided by Nogales S.R.L, Argentina. The walnuts were stored (warehouse) at room temperature until they were bought in May, 2016. Then, they were stored in the freezer $\left(-20^{\circ} \mathrm{C}\right)$ until the beginning of the experiment.

Carboxymethyl cellulose (CMC) (Parafarm (R) and methyl cellulose (MC) (Parafarm $\left.{ }^{\circledR}\right)$ were obtained from SAPORITI S.A.C.I.F.I.A. (Buenos Aires, Argentina), and whey protein isolates (WP) were purchased from Todo Droga (Córdoba, Argentina) to prepare the coatings.

\subsection{Methods}

\subsubsection{Edible coating preparation}

CMC coating: A $0.5 \%(\mathrm{w} / \mathrm{v})$ solution of CMC was prepared and glycerol was added as a plasticizer $(1.9 \%, \mathrm{w} / \mathrm{v})$ (Grosso et al., 2017).

MC coating: A $2 \%(\mathrm{w} / \mathrm{v})$ solution of $\mathrm{MC}$ was prepared and glycerol was added as a plasticizer $(1.9 \%)$ (Grosso et al., 2017).

WP coating: A $11 \%(\mathrm{w} / \mathrm{w})$ solution of WP was prepared and $11 \mathrm{~g}$ glycerol were added to the solution (Grosso et al., 2017).

Walnuts were immersed in containers with the corresponding coating solution $(\mathrm{CMC}, \mathrm{MC}$, and WP) for 5 minutes. After that, they were removed and put in a strainer for 5 minutes to let the excess solution drip off. Finally, the coated walnuts were placed at room temperature under hood for $24 \mathrm{~h}$ to dry off the excess moisture. The final moisture contents $(\%)$ in the walnut kernels after the drying process were: 4.05 in WC, 4.52 in WCMC; 5.94 in WMC and 4.24 in WWP. Four treatments were prepared using unshelled walnuts: uncoated walnuts (WC, control sample); and coated walnuts with CMC (WCMC), MC (WMC), and WP (WWP).

\subsubsection{Storage study}

The walnuts (WC, WCMC, WMC, and WWP) were stored in $15 \times 25 \times 5 \mathrm{~cm}$ plastic containers (Tupperware, Buenos Aires, Argentina) at room temperature $\left(23 \pm 2{ }^{\circ} \mathrm{C}\right)$ under normal atmosphere conditions $\left(20-21 \% \mathrm{O}_{2} ; 60-70 \% \mathrm{RH}\right)$ for 210 days, which are the usual conditions for storing these products. Each container was loaded with $1 \mathrm{~kg}$ of walnut kernels. The samples were analyzed for physical-chemical parameters (peroxide value, carotenoid content, conjugated dienes and trienes and 4 volatile compounds) at $0,35,70,105,140,175$ and 
210 storage days. The experimental design consisted of 4 treatments (WC, WWP, WCMC, and WMC) $\mathrm{x} 3$ replicates of each treatment x 10 chemical variables $\times 7$ periods of time. The physical variable (color) was determined at the beginning and at the end of storage.

\subsubsection{Chemical analysis: Peroxide value, conjugated dienes and trienes, and carotenoid content}

These analysis were performed on walnut oil. The oil was obtained by cold pressing $20 \mathrm{~g}$ of walnuts, using a 20 -ton press (HE-DU, Hermes I. Dupraz S.R.L., Córdoba, Argentina). Peroxide value was measured according to AOAC (2010). Conjugated dienes and trienes were measured at $232 \mathrm{~nm}$ and 268 $\mathrm{nm}$, respectively (COI, 2001). Carotenoid contents were analyzed at $470 \mathrm{~nm}$ following the procedures described by Mosquera et al., (1991).

\subsubsection{Volatile analysis}

The volatile compound analysis of the walnut samples was performed in walnut kernels by headspace solid phase microextraction fiber (HS-SPME) according to Martin et al. (2016). The SPME fiber used was divinylbenzene/carboxen/polydimethylsiloxane (DVB/CAR/PDMS) 50/30 $\mu \mathrm{m}$, StableFlex, $1-\mathrm{cm}$ long (Supelco). Raw walnut kernels (2 g) were ground using a mill (FBR 3 ( $)$ Decalab S. R. L, Buenos Aires, Argentina) and placed in vials at $70{ }^{\circ} \mathrm{C}$ for $20 \mathrm{~min}$. The fiber was exposed to the vial headspace for $10 \mathrm{~min}$ and then injected into a Gas Chromatograph (Perkin Elmer Clarus 600 ) coupled with a mass detector. An ELITE 5MS $(30 * 0.25 \mathrm{~mm}$ i.d., $0.25 \mathrm{~mm}$ film thickness; Perkin Elmer) column was used. Chromatographic responses of detected volatile compounds (peak area electronic counts) were monitored for comparison of each compound among samples (Quiroga, Asensio and Nepote, 2014).

\subsubsection{Physical analysis: walnut oil color}

Color measurements were taken on the oil samples on a white background with a Minolta colorimeter (Minolta CM-508d, Tokyo, Japan). The CieLab parameters $\left(L^{*}, a^{*}\right.$ and $\left.b^{*}\right)$ for each sample were measured at least in five random positions. The measurements were performed at 3 different periods of time: $0,105,210$ days.

\subsubsection{Statistical analysis}

Three replicates of the experiment were made. The data were analyzed using InfoStat software, version 2016p. A two-way analysis of variance (factors: 'treatment' and 'time') and LSD-Fisher was used to detect significant differences among treatments (ANOVA, $\alpha=0.05$ ). Pearson coefficients were calculated to establish correlations among dependent variables. A principal component analysis (PCA) was performed on the correlation matrix of normalized data. The objective of the PCA analysis was to explore associations among treatments and variables. A Cluster Analysis (CA) was carried out to obtain groups of walnut treatments with similar characteristics. Sample similarities were calculated using the Euclidean distance, and groups of walnut treatments with similar characteristics were obtained using the unweighted pair-group method (UPGMA).

\section{RESULTS AND DISCUSSION}

\subsection{Chemical analysis: Peroxide value, conjugated dienes and trienes, and carotenoid content}

The changes in the PV and CD and CT of WC, WCMC, WMC and WWP are illustrated in Figure 1. Peroxide formation proceeds slowly in the initial stages of oxidation. However, in the later stages, it acts as a catalyst in oil oxidation (Moslehi et al., 2015). In this study, the PV increased for all walnut samples during the storage period. The increase was the highest in WC (Figure 1a). The PV measured on the first day of storage ( 0 days) was $0.37 \mathrm{meqO}_{2} /$ $\mathrm{kg}$, and no significant differences among the treatments were detected $(\alpha>0.05)$. In the middle of the storage period (day 105), differences in the mean values among treatments began to appear. The Argentinean Food Code allows for a maximum of $10 \mathrm{meqO}_{2} / \mathrm{kg}$ for nut products (Riveros et al., 2013). Moreover, correlation coefficients higher than 0.6 were observed among the chemical variables (PV, $\mathrm{AV}$ and $\mathrm{CD}$ ) and the sensory variables (oxidized and cardboard flavors) related to the lipid oxidation process (Olmedo et al., 2009). On the last day of storage (day 210), WMC exhibited the lowest PV $\left(1.20 \mathrm{meqO}_{2} / \mathrm{kg}\right)$, followed by WCMC $\left(2.26 \mathrm{meqO}_{2} /\right.$ $\mathrm{kg})$, and WWP (2.53 $\left.\mathrm{meqO}_{2} / \mathrm{kg}\right)$. WC experienced the highest increase in PV $\left(3.06 \mathrm{meqO}_{2} / \mathrm{kg}\right)$. These results showed that the application of the $\mathrm{CMC}$, MC and WP coatings to walnut samples generated a protective effect on the product during the storage period. In terms of the PV, the coating that had the most significant protective effect was MC. Methyl cellulose is a flexible and transparent polysaccharide tailored from cellulose. It was reported to have moderate strength, resistance to oil and fat migration, and acts as moderate barrier to moisture and oxygen (Maftoonazad and Ramaswamy, 2005). Because of these factors, it can be assumed that methyl cellulose inhibits oxidation in the coated walnut kernels. 
(a)

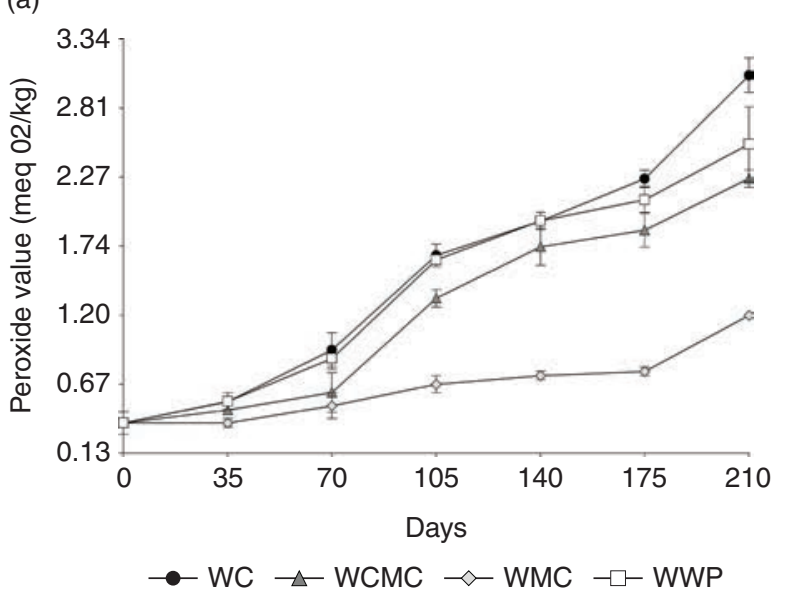

(c)

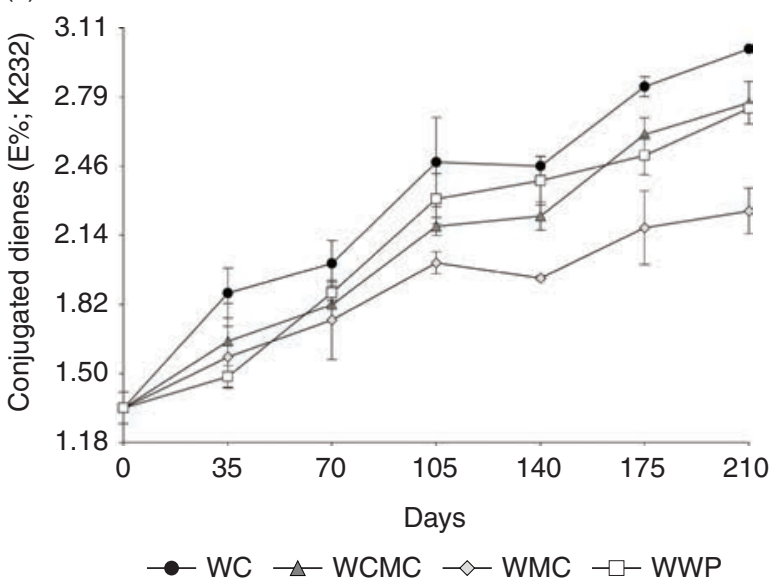

(b)

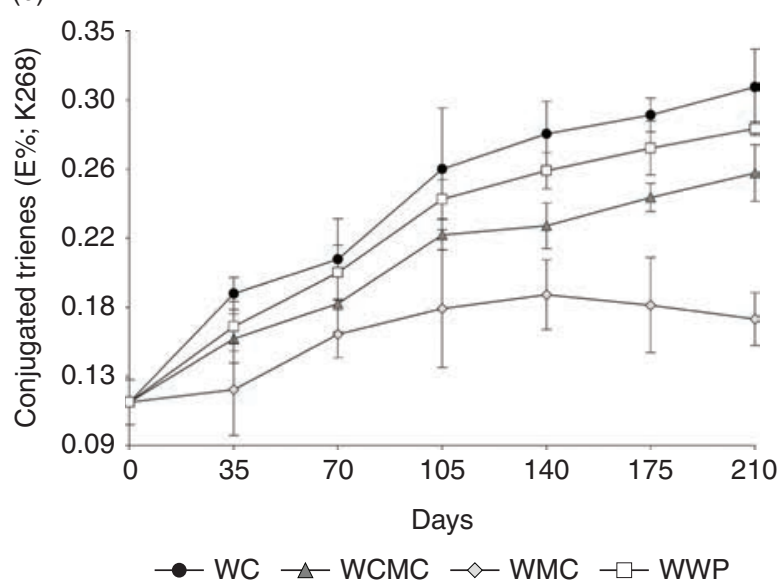

(d)

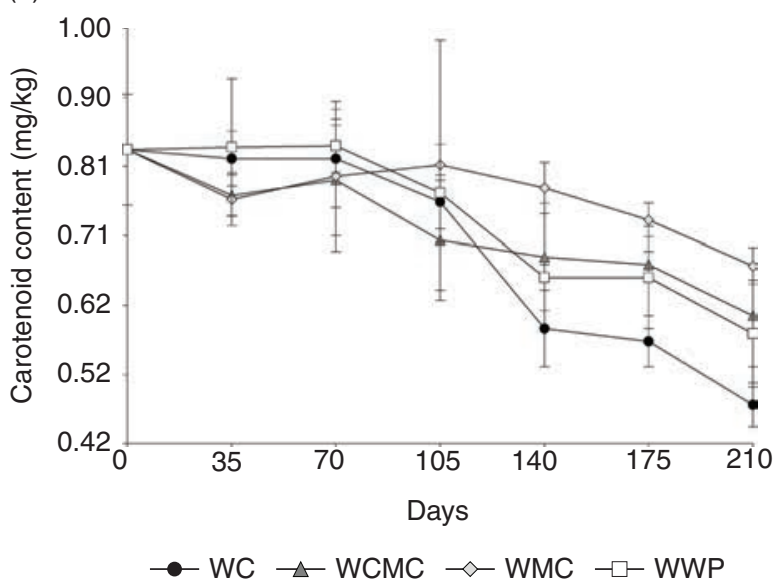

Figure 1. (a) Peroxide value (meq O2/kg), (b) Conjugated trienes (E1\%, K268), (c) Conjugated dienes (E1\%, K232), (d) Carotenoid content $(\mathrm{mg} / \mathrm{kg})$ in walnut samples coated with carboximethyl cellulose (WCMC), methyl cellulose (WMC) and whey protein (WWP); and walnuts without coating (WC) analyzed during 210 days of storage $(\mathrm{n}=3 ; \alpha=0.05)$.

Moslehi et al., (2015) found that pistachios coated with MC had the lowest PV after four months of storage, and Grosso et al., (2017) found that MC coating had a preserving effect in the intensity of the characteristic walnut flavor which reduced the development off-flavors related to lipid oxidation. In a different study, the maximum PV occurred in non-coated control samples; walnuts coated with chitosan and green tea extract had significantly $(\mathrm{p}<0.05)$ lower PV value after 18 weeks of storage (Sabaghi et al., 2015). Other works have shown that CMC coatings also provide significant protection against lipid oxidation in other food products such as almonds (Larrauri et al., 2016) and peanuts (Riveros et al., 2013).

The CD is related to the formation of hydroperoxides, conjugated dienes and carboxylic compounds, while CT reflects the concentrations of secondary oxidation products formed from the initial compounds detected at $232 \mathrm{~nm}$ (Ancin Azpilicueta and Martínez Remírez, 1991) The samples showed an increase in both parameters during the storage period (Figure 2.b). On storage day 0, there were no significant differences among the treatments $(\mathrm{p} \leq 0.001)$. Significant differences were found at subsequent storage periods. On the last day measured, WMC exhibited the lowest values for CD and CT (2.26 and 0.17, respectively) while, WC displayed the greatest values for these parameters (3.01 and 0.31 , respectively). Once more, $\mathrm{MC}$ acted as a barrier between walnuts and the atmosphere, preventing gas exchange and, as a consequence, lipid oxidation. This was previously studied in coated pistachios (Moslehi et al., 2015) and avocados (Maftoonazad and Ramaswamy, 2005) where MC coating lessened moisture losses and respiration rates. Other studies have also found lower values of $\mathrm{CD}$ in products protected with edible coatings. 
(a)

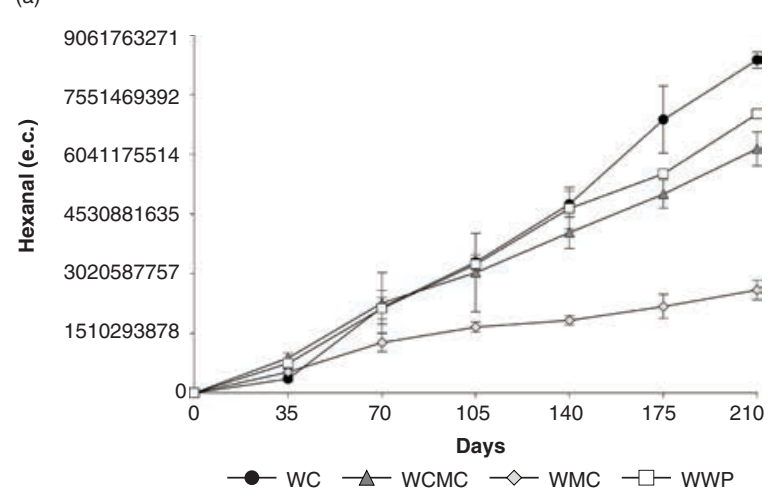

(c)

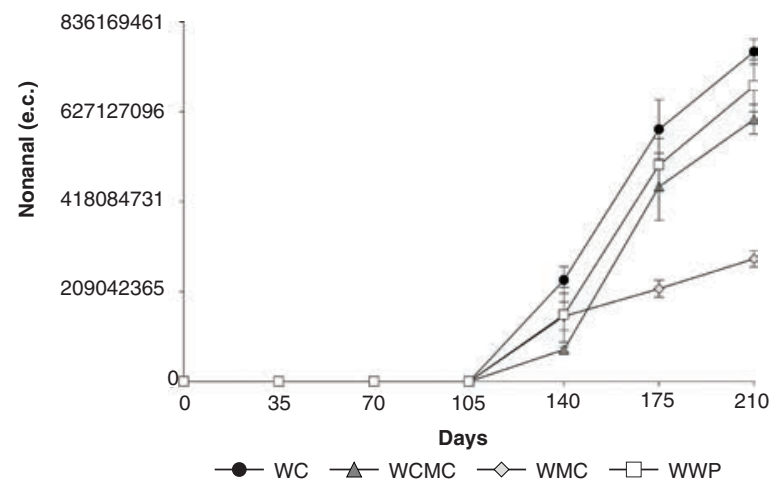

(b)

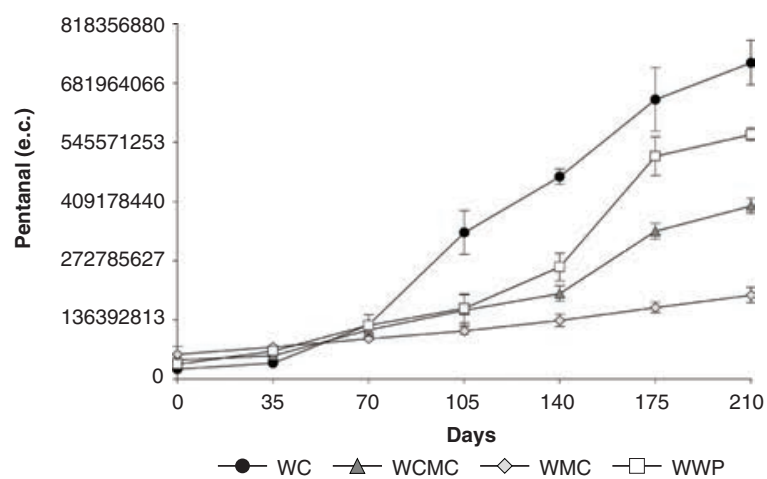

(d)

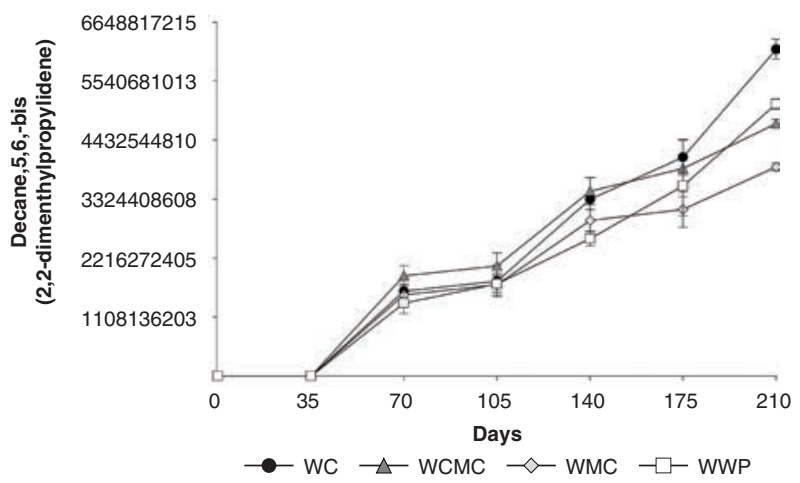

Figure 2. (a) Hexanal, (b) Pentanal, (c) Nonanal, (d) Decane, 5,6-bis (2,2-dimethylpropylidene) measured in electronic counts in walnut samples coated with carboximethyl cellulose (WCMC), methyl cellulose (WMC) and whey protein (WWP), and walnuts without coating (WC) analyzed during 210 days of storage $(\mathrm{n}=3 ; \alpha=0.05)$.

Riveros et al., (2013) reported that peanuts coated with $\mathrm{CMC}$ presented the lowest $\mathrm{CD}$ after 56 days of storage, followed by samples coated with MC. In a different work, Riveros et al., (2016) also reported that sunflower seeds without coating had higher CD than sunflower seeds coated with CMC.

Carotenoids are compounds that play an important role in the oxidative stability of walnuts because they can act as antioxidants (Özrenk et al., 2012). The main cause of carotenoid loss is oxidation (Dias, Camões and Oliveira, 2014). The carotenoid content of the samples decreased during the storage period, although no significant differences in the mean values were detected until storage day 140 (Fig 1.d). On the last day of storage, the sample with the lowest carotenoid content was WC $(0.48 \mathrm{mg} / \mathrm{kg})$, followed by WCMC, WMC, and WWP $(0.60,0.67$, and $0.58 \mathrm{mg} / \mathrm{kg}$, respectively). This indicates that the WC sample suffered greater oxidation, while the coated samples were protected against the oxidation of carotenoids. In a research investigating the effect of edible coatings consisting of native and modified maize and cassava starches on carotenoid retention in pumpkin during drying showed that carotenoid degradation was minimized and therefore, a significant improvement was found in the carotenoid contents of dehydrated pumpkin slices which were previously coated with native and modified maize and cassava starches (Yousuf et al., 2018).

\subsection{GC-MS volatile compounds analysis}

In the present study, different volatile compounds were detected in walnut kernels by $\mathrm{GC} /$ MS analysis. Table 1 summarizes the compounds identified in the walnut treatments on the first day of storage. During the storage period, the quantities of the volatile compounds changed (Figure 2). The most remarkable changes occurred in pentanal, nonanal, hexanal, and decane,5,6bis (2,2-dimethylpropylidene). These compounds increased during the storage period and reached their maximum values on the last day measured (day 210). The presence of hexanal and nonanal is directly related to the development of rancid flavors in lipid-rich foods (Quiroga, Asensio and Nepote, 2014). On day 0, neither hexanal nor nonanal were found in any of the samples (Table 1). During the storage period, hexanal 
TABLE 1. Volatile compounds (electronic counts $10^{6}$ ) per gram of walnuts coated with carboximethyl cellulose (WCMC), methyl cellulose (WMC) and whey protein (WWP), and walnuts without coating (WC) analyzed in fresh product (storage day 0).

\begin{tabular}{|c|c|c|c|c|}
\hline \multirow[b]{2}{*}{ Volatile compound } & \multicolumn{4}{|c|}{ Treatment } \\
\hline & WC $^{\mathrm{a}}$ & WCMC $^{\mathrm{a}}$ & WMC $^{\mathbf{a}}$ & WWP $^{\mathbf{a}}$ \\
\hline \multicolumn{5}{|l|}{ Alcohols } \\
\hline Cyclopropyl carbinol & $42.22 \pm 5.78 \mathrm{a}$ & $49.29 \pm 0.73 \mathrm{a}$ & $49.73 \pm 3.25 \mathrm{a}$ & $46.40 \pm 4.97 \mathrm{a}$ \\
\hline \multicolumn{5}{|l|}{ Aldehydes } \\
\hline Pentanal & $22.62 \pm 3.59 \mathrm{a}$ & $44.22 \pm 4.55 b$ & $56.93 \pm 7.73 b$ & $34.27 \pm 1.45 \mathrm{a}$ \\
\hline Butanal & $56.23 \pm 4.40 \mathrm{~b}$ & $40.83 \pm 3.36 \mathrm{a}$ & $44.87 \pm 1.83 \mathrm{a}$ & $50.46 \pm 3.28 \mathrm{ab}$ \\
\hline \multicolumn{5}{|l|}{ Aliphatic hydrocarbons } \\
\hline Nonane & $99.08 \pm 9.90 \mathrm{a}$ & $107.54 \pm 4.69 \mathrm{a}$ & $109.54 \pm 6.74 \mathrm{a}$ & $125.14 \pm 9.72 \mathrm{a}$ \\
\hline Tridecane & $82.52 \pm 5.61 \mathrm{a}$ & $88.78 \pm 1.17 \mathrm{a}$ & $85.12 \pm 7.33 \mathrm{a}$ & $77.14 \pm 1.50 \mathrm{a}$ \\
\hline Tetradecane & $1005.19 \pm 103.91 \mathrm{a}$ & $1037.93 \pm 28.97 \mathrm{a}$ & $1061.90 \pm 128.28 \mathrm{a}$ & $958.26 \pm 60.88 \mathrm{a}$ \\
\hline Pentadecane & $973.34 \pm 46.06 \mathrm{a}$ & $1096.18 \pm 74.28 \mathrm{a}$ & $919.53 \pm 10.06 \mathrm{a}$ & $1035.50 \pm 97.56 \mathrm{a}$ \\
\hline Hexadecane & $1340.96 \pm 2.65 \mathrm{a}$ & $1611.12 \pm 83.74 \mathrm{a}$ & $1457.32 \pm 111.56 \mathrm{a}$ & $1354.51 \pm 120.74 \mathrm{a}$ \\
\hline Pentadecane, 2-6-10-14-tetramethyl & $54.70 \pm 9.77 \mathrm{a}$ & $50.58 \pm 4.75 \mathrm{a}$ & $44.89 \pm 2.92 \mathrm{a}$ & $49.27 \pm 4.41 \mathrm{a}$ \\
\hline Dodecane, 2,6,10-trimethyl- & $362.98 \pm 55.88 \mathrm{a}$ & $420.24 \pm 26.98 \mathrm{a}$ & $377.04 \pm 12.37 \mathrm{a}$ & $384.61 \pm 18.52 \mathrm{a}$ \\
\hline Decane,5,6-bis(2,2-dimethylpropylidene) & ND & ND & ND & ND \\
\hline \multicolumn{5}{|l|}{ Aromatic hydrocarbons } \\
\hline Benzene, 1-methyl-2-(1-methylethyl)- & $295.43 \pm 57.90 \mathrm{a}$ & $292.79 \pm 30.65 \mathrm{a}$ & $261.32 \pm 20.61 \mathrm{a}$ & $264.78 \pm 4.81 \mathrm{a}$ \\
\hline \multicolumn{5}{|l|}{ Benzene derivates } \\
\hline Benzothiazole & $39.26 \pm 17.74 \mathrm{ab}$ & $75.34 \pm 14.48 \mathrm{a}$ & $64.43 \pm 6.96 \mathrm{~b}$ & $90.05 \pm 13.12 b$ \\
\hline $\begin{array}{l}\text { Phenol, 2,6-bis(1,1-dimethylethyl)-4-methyl-, } \\
\text { methylcarbamate }\end{array}$ & $124.89 \mathrm{a}$ & $199.30 \pm 5.75 \mathrm{~b}$ & $138.08 \pm 11.43 \mathrm{a}$ & $145.48 \pm 11.67 \mathrm{a}$ \\
\hline \multicolumn{5}{|l|}{ Organic acids } \\
\hline Oxalic acid & $35.77 \pm 4.21 \mathrm{a}$ & $3.502 \pm 1.75 \mathrm{a}$ & $30.79 \pm 2.38 \mathrm{a}$ & $32.21 \pm 1.17 \mathrm{a}$ \\
\hline Oxalic acid, allyl pentadecyl ester & $106.29 \pm 7.49 \mathrm{a}$ & $125.97 \pm 6.52 \mathrm{a}$ & $102.30 \pm 6.51 \mathrm{a}$ & $112.81 \pm 8.59 \mathrm{a}$ \\
\hline \multicolumn{5}{|l|}{ Amines } \\
\hline N-Thio-valero-morpholine & $351.97 \pm 33.29 \mathrm{a}$ & $356.50 \pm 31.21 \mathrm{a}$ & $277.33 \pm 31.18 \mathrm{a}$ & $299.98 \pm 18.01 \mathrm{a}$ \\
\hline \multicolumn{5}{|l|}{ Terpenes } \\
\hline $\begin{array}{l}\text { 3-Cyclohexen-1-ol, } \\
\text { 4-methyl-1-(1-methylethyl)- }\end{array}$ & $148.04 \pm 20.35 \mathrm{a}$ & $135.19 \pm 2.55 \mathrm{a}$ & $132.32 \pm 13.91 \mathrm{a}$ & $135.63 \pm 14.31 \mathrm{a}$ \\
\hline \multicolumn{5}{|l|}{ Esters } \\
\hline Sulfurous acid, cyclohexylmethyl hexyl ester & $743.95 \pm 24.09 \mathrm{a}$ & $888.97 \pm 69.30 \mathrm{a}$ & $691.59 \pm 108.10 \mathrm{a}$ & $775.98 \pm 69.26 \mathrm{a}$ \\
\hline
\end{tabular}

$\mathrm{ND}=$ Not detected

a Mean values \pm standard deviations followed by different letters in each row indicate significant differences at $\alpha=0.05$ ( $\mathrm{n}=3$, LSD Fisher).

started to increase from day 35 , while nonanal was detected from day 126 (Figures 2.a and 2.c). On the last day of measurement, significant differences among walnut treatments were found $(\mathrm{p} \leq 0.001)$. WC presented the highest values for hexanal, nonanal and pentanal. On the other hand, WMC was the treatment which presented the lowest amounts of volatile compounds related to lipid oxidation. Larrauri et al., (2016) reported for roasted coated almonds stored for 126 days at $40{ }^{\circ} \mathrm{C}$ that hexanal and nonanal increased in all samples. However, almonds coated with CMC and
CMC+antioxidants had significantly lower levels of these compounds. Crowe et al., (2002) showed that the levels of hexanal (aldehyde) increased as walnut sensory quality deteriorated. Elmore et al., (2005) reported that hexanal was the volatile compound present in the highest quantities in walnut samples, followed by 1-pentanol, pentanal, 1-hexanol and 1-penten-3-ol. Most of these compounds are mainly formed from the oxidation of linoleic acid.

Another compound that showed intriguing behavior was decane,5,6-bis (2,2-dimethylpropylidene) 


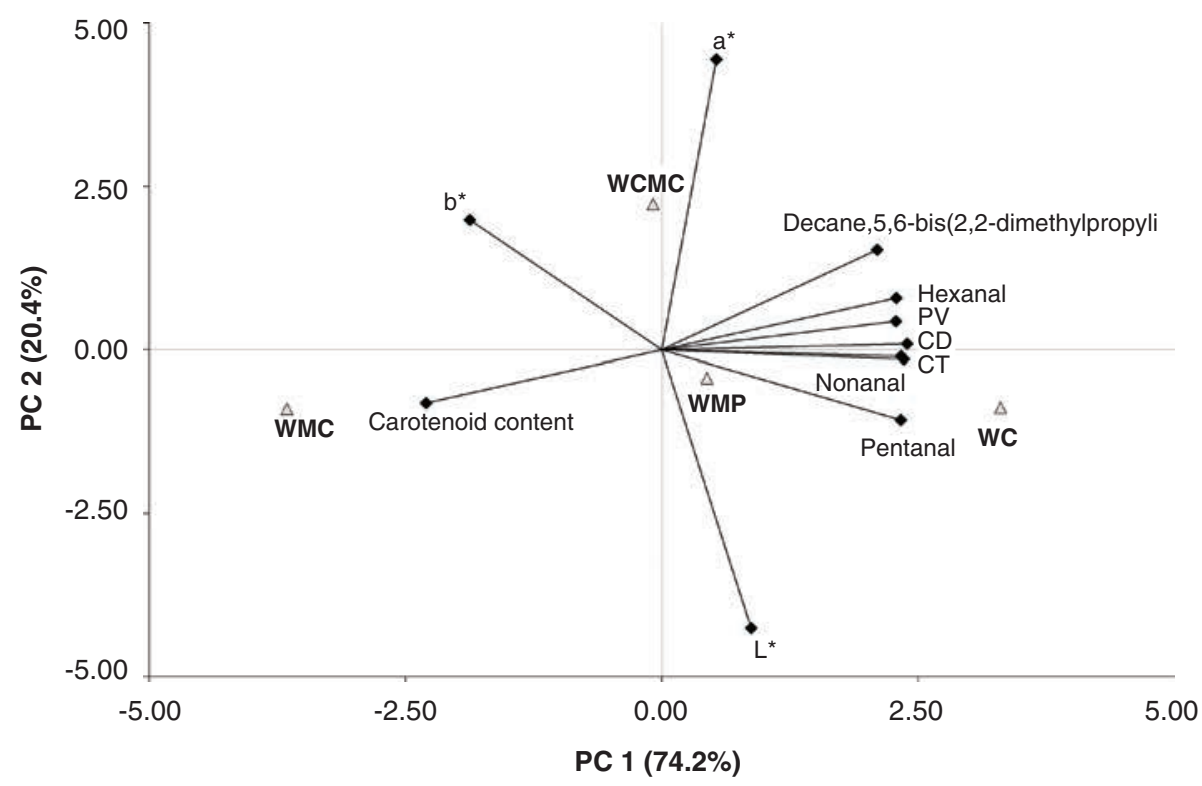

FIGURE 3. Bi-plots of principal component analysis. Independent variables: peroxide value (PV), conjugates dienes (CD), conjugated trienes (CT), hexanal, nonanal, pentanal, decane, 5,6-bis (2,2-dimethylpropylidene)-, $\mathrm{a}^{*}, \mathrm{~b}^{*}, \mathrm{~L}^{*}$ and carotenoid content. Treatments: walnuts coated with carboximethyl cellulose (WCMC), methyl cellulose (WMC) and whey protein (WWP), and walnuts without coating (WC).

(Figure 2.d.) Martin et al., (2016) reported that this compound was found in peanut kernels stored in different types of packaging. Decane, 5,6-bis (2,2-dimethylpropylidene) showed an increase from day 0 to day 210 . On the first day of measurement, this compound was not found in any of the treatments, while on the last day measured, WC presented the highest amount, followed by WWP and WCMC. WMC contained the lowest quantity.

\subsection{Physical analysis: Color}

Walnut color has a direct relationship with pigment and phenolic contents which are contained mainly in the skins of the seeds (Christopoulos and Tsantili, 2011). These compounds play an important role in protecting fatty acids from oxidation (Salcedo, López de Mishima and Nazareno, 2010). On the other hand, it is known that lipoxygenase (LOX) catalyses the hydroperoxidation of lipids containing free fatty acids with an activated methylene group between the two double bonds such as linoleic and $\alpha$-linolenic acids, and has a significant effect on the stability, taste and color of plant-based products (Baysal and Demirdoven, 2007). Like most enzymes, LOX activity is accelerated by adding water or solutions to food products and can affect their color. Color changes in walnut kernels during storage were evaluated by analyzing the changes in lightness ( $\mathrm{L}$ value), green/red components ( $\mathrm{a}^{*}$ value), and blue/yellow components
( $b^{*}$ value). At the beginning of the experiment, the color parameters of WC, WCMC, WMC and WWP showed negative values for $\mathrm{a}^{*}$, positive values for $b^{*}$ and a high lightness value $\left(\mathrm{L}^{*}\right)$. At the end of storage, the $a^{*}$ value was more negative in WC (-1.145) suggesting an increase in its greenness, followed by WMC and WWP and WCMC. This change could be attributed to the oxidation of skin pigments. Opposite results were found in coated avocados with $\mathrm{MC}$ where the a* value was more negative in coated samples, indicating the avocado skin to be greener; then, with the passing of time, the color shifted towards a positive $\mathrm{a}^{*}$ value, which indicates more redness in color as a result of ripening (Maftoonazad and Ramaswamy, 2005). In the case of $b^{*}$, there was an increase compared to the first day, but no significant differences were found among samples. Finally, the $\mathrm{L}^{*}$ value decreased for all samples. On the last day measured (210), WMC (70.46) and WCMC (70.37) presented the lowest values, followed by WWP (70.66) and WC (70.75). This color change in the $L^{*}$ value indicated lower brightness due to storage time. Manzocco et al., (2001) also reported that the $\mathrm{L}^{*}$ in walnuts decreased during storage. In addition, Maftoonazad and Ramaswamy (2005) found that coated samples with MC presented lower decreases in $L^{*}$ values. A descriptive study about the sensory qualities of walnuts with edible coatings (Grosso et al., 2017) also showed that the color intensity of the kernels increased during storage. In addition, a 
direct relationship between this attribute and oxidized flavor was found. In this research, the browning and color quality deterioration which occurred in the samples probably occurred because of LOX enzymatic oxidation.

\subsection{Principal component analysis}

A PCA was conducted in order to understand the behavior of the different treatments with respect to their ability to preserve the oxidative stability of walnuts during storage. The biplot obtained from the first two principal components (PC) in the PCA is presented in Fig. 3. The first two PC explained $94.4 \%$ data variability over the 210 storage days. CD, CT, PV, L*, a*, b*, nonanal, hexanal, pentanal and decane,5,6-bis (2,2-dimethylpropylidene) were placed on the right side (PC1) of the biplot. There was a positive association among these variables; and they were negatively related to carotenoids and $b^{*}$. WC was placed on the right side of the plot close to the volatile compounds and to the lipid oxidation indicators. On the other hand, WMC and WCMC were placed on the left side of the plot opposite these indicators and the WC sample. This behavior was consistent with the obtained results, where edible coatings presented a better performance in protecting walnuts from deterioration, and in particular, the sample coated with MC. In the plot, WMC was positively associated with carotenoid content, which is an indicator of product quality preservation.

These associations were confirmed by the correlation analysis (Pearson coefficients). Pentanal and hexanal showed the strongest correlation of all the volatile compounds analyzed, represented by a coefficient of 0.93 . Pentanal and hexanal were also highly correlated with nonanal with coefficients of 0.86 and 0.84 , respectively. Decane, 5,6-bis (2,2-dimethylpropylidene) was most strongly correlated with hexanal (0.86). Larrauri et al., (2016) also found a positive correlation between hexanal and nonanal in a storage study performed on coated almonds. In the current study, chemical lipid oxidation indicators were also correlated. For example, PV showed a 0.89 correlation coefficient with CD, and 0.84 with CT. CD was highly correlated with CT (0.87). Martin et al., (2016) also found a positive correlation between CD and PV in a storage study on peanut samples stored in different types of packaging, while Asensio et al., (2011) found a similar correlation of PV with CD and CT in a stability study on olive oil flavored with oregano essential oil. In the present study, these chemical indicators were also correlated with the volatile compounds. Hexanal was correlated with PV and CD (Pearson's coefficients of 0.95 and 0.89 , respectively). Quiroga, Asensio and Nepote (2014) reported a positive association between hexanal content and oxidation

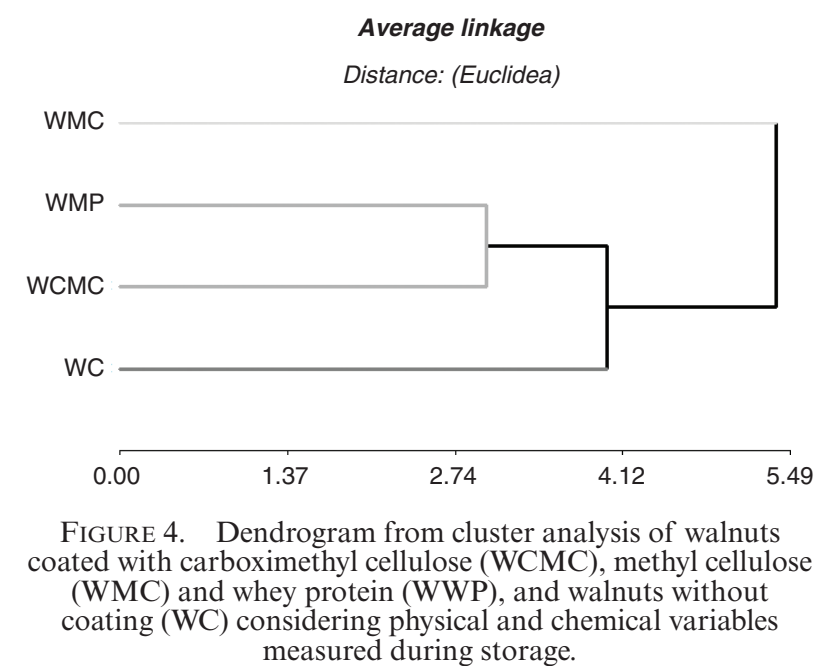
measured during storage.

indicators (peroxide value) in a storage study on sunflower seeds with the addition of antioxidants. In the present study, carotenoids were negatively correlated with the chemical oxidation indicators mentioned above. Asensio et al., (2011) also found negative correlations for carotenoid content with CD, CT and PV in samples of extra-virgin olive oil with added oregano essential oil.

\subsection{Cluster analysis (CA)}

The results from the CA, which consider the dependent variables studied, are presented as a dendogram (Fig. 4). Three groups were identified in the cluster analysis. Group 1 was formed by WC; Group 2 was formed by WCMC and WWP; and Group 3 was formed by WMC. These results indicate that the control sample, which experienced the greatest changes during storage, was the most oxidized sample and different from the rest of the treatments. Based on the measured indicators, WCMC and WWP showed intermediate behavior. WMC was alone in Group 3 due to its different performance during storage. This treatment was the least affected by the oxidation process. This result was in accordance with the PCA, in which WMC was the sample most separated from other samples in the bi-plot and was placed on the opposite side of the graph with respect to the lipid oxidation indicators.

\section{CONCLUSIONS}

In general, the use of carboxy methyl cellulose, methyl cellulose and whey protein edible coatings on walnuts helps to prolong the shelf-life of the kernels by preserving their chemical and physical quality properties. The use of methyl cellulose coating lessens the deterioration of walnut kernels. 
Therefore, the use of edible coatings, especially those containing methyl cellulose, can be used in the food industry as an alternative method to prolong the overall quality and shelf-life of walnuts.

\section{ACKNOWLEDGMENTS}

This research was supported by Consejo Nacional de Investigaciones Científicas y Técnicas (CONICET) and Secretaría de Ciencia y Tecnología (SECYT-UNC).

\section{REFERENCES}

Ancin Azpilicueta MC, Martínez Remírez MT. 1991. Estudio de la degradación de los aceites de oliva sometidos a fritura. I. Determinación estadística del parámetro que mejor cuantifica esta degradación. Grasas Aceites 42, 22-31.

Asensio CM, Nepote V, Grosso NR. 2011. Chemical Stability of Extra-Virgin Olive Oil Added with Oregano Essential Oil. J. Food Sci. 76, 445-450. https://doi.org/10.1111/j. 1750-3841.2011.02332.x

Baysal T, Demirdoven A. 2007. Lipoxygenase in fruits and vegetables: A review. Enzyme Microb. Technol. 40, 491-496. https://doi.org/10.1016/j.enzmictec.2006.11.025

Christopoulos MV, Tsantili E. 2011. Effects of temperature and packaging atmosphere on total antioxidants and colour of walnut (Juglans regia L.) kernels during storage. Sci. Hortic. (Amsterdam). 131, 49-57. https://doi.org/10.1016/j. scienta.2011.09.026

Crowe TD, Crowe TW, Johnson LA, White PJ. 2002. Impact of extraction method on yield of lipid oxidation products from oxidized and unoxidized walnuts. J. Am. Oil Chem. Soc. 79 , 453-456. https://doi.org/10.1007/s11746-002-0505-7

Dias MG, Camões MFGFC, Oliveira L. 2014. Carotenoid stability in fruits, vegetables and working standards - effect of storage temperature and time. Food Chem. 156, 37-41. https://doi.org/10.1016/j.foodchem.2014.01.050

Elmore JS, Nisyrios I, Mottram DS. 2005. Analysis of the headspace aroma compounds of walnuts (Juglans regia L.). Flavour Fragr. J. 20, 501-506. https://doi.org/10.1002/ffj.1477

Embuscado ME, Huber KC. 2009. Edible Films and Coatings for Food Applications. Springer Media, New York, USA.

Gayol MF, Soliani S, Quiroga PR, Nepote V, Grosso NR. 2009. Effect of prickly pear and algarrobo pod syrup coatings on consumer acceptance and stability of roasted almonds. J. Sci. Food Agric. 89, 2415-2420. https://doi.org/10.1002/ jsfa. 3737

Grosso AL, Asensio CM, Grosso NR and Nepote V. 2017. Sensory Quality Preservation of Coated Walnuts. J. Food Sci. 82, 185-193. https://doi.org/10.1111/1750-3841.13570

Kang HJ, Kim SJ, You YS, Lacroix M, Han J. 2013. Inhibitory effect of soy protein coating formulations on walnut (Juglans regia L.) kernels against lipid oxidation. LWT - Food Sci. Technol. 51, 393-396. https://doi.org/10.1016/j.lwt.2012.10.019

Larrauri M, Demaría MG, Ryan LC, Asensio CM, Grosso NR, Nepote V. 2016. Chemical and Sensory Quality Preservation in Coated Almonds with the Addition of Antioxidants. J. Food Sci. 81, 208-215. https://doi.org/ 10.1111/1750-3841.13164

Maftoonazad N, Ramaswamy HS. 2005. Postharvest shelf-life extension of avocados using methyl cellulose-based coating. LWT - Food Sci. Technol. 38, 617-624. https://doi. org/10.1016/j.lwt.2004.08.007

Manzocco L, Mastrocola D, Nicoli MC, Marangoni V. 2001. Review of non-enzymatic browning and antioxidant capacity in processed foods. Trends Food Sci. Technol. J. 11, 340-346. https://doi.org/10.1016/S0924-2244(01)00014-0
Martin MP, Nepote V, Grosso NR. 2016. Chemical, sensory, and microbiological stability of stored raw peanuts packaged in polypropylene ventilated bags and high barrier plastic bags. LWT - Food Sci. Technol. 68, 174-182. https:// doi.org/10.1016/j.lwt.2015.12.031

Martínez M, Barrionuevo G, Nepote V, Grosso NR, Maestri D. 2011. Sensory characterisation and oxidative stability of walnut oil. Int. J. Food Sci. Technol. 46, 1276-1281. https:// doi.org/10.1111/j.1365-2621.2011.02618.x

Martínez ML, Penci CP, Ixtaina V, Ribotta PD, Maestri D. 2013. Effect of natural and synthetic antioxidants on the oxidative stability of walnut oil under different storage conditions. LWT - Food Sci. Technol. 51, 44-50. https:// doi.org/10.1016/j.lwt.2012.10.021

Mehyar GF, Al-Ismail K, Han JH, Chee GW. 2012. Characterization of Edible Coatings Consisting of Pea Starch, Whey Protein Isolate, and Carnauba Wax and their Effects on Oil Rancidity and Sensory Properties of Walnuts and Pine Nuts. J. Food Sci. 77, 52-59. https://doi. org/10.1111/j.1750-3841.2011.02559.x

Moslehi Z, Garmakhany AD, Araghi M, Moslehi M. 2015. Effect of methyl cellulose coating on physicochemical properties, porosity, and surface diameter of pistachio hull. Food Sci. Nutr. 3, 355-361. https://doi.org/10.1002/ fsn3.227

Mínguez-Mosquera IM, Rejano-Navarro L, Gandul-Rojas B, Sánchez-Gomez AH, Garrido-Fernández J. 1991. Colorpigment correlation in virgin olive oil. J. Am. Oil Chem. Soc. 68, 332-336. https://doi.org/10.1007/BF02657688

Özrenk K, Javidipour I, Yarilgac T, Balta F, Gündogdu M. 2012. Fatty acids, tocopherols, selenium and total carotene of pistachios (P. vera L.) from Diyarbakir (Southeastern Turkey) and walnuts (J. regia L.) from Erzincan (Eastern Turkey). Food Sci. Technol. Int. 18, 55-62. https://doi. org/10.1177/1082013211414174

Quiroga PR, Asensio M, Nepote V. 2014. Antioxidant effects of the monoterpenes carvacrol, thymol and sabinene hydrate on chemical and sensory stability of roasted sunflower seeds. J. Sci. Food Agric. 95, 471-479. https://doi. org/10.1002/jsfa.6744

Riveros CG, Martin MP, Aguirre A, Grosso NR. 2018. Film preparation with high protein defatted peanut flour: characterisation and potential use as food packaging. Int. J. Food Sci. Technol. 53, 969-975. https://doi.org/10.1111/ ijfs. 13670

Riveros CG, Mestrallet MG, Quiroga PR, Nepote V, Grosso NR 2013. Preserving sensory attributes of roasted peanuts using edible coatings. Int. J. Food Sci. Technol. 48, 850-859. https://doi.org/10.1111/ijfs. 12036

Riveros CG, Nepote V, Grosso NR. 2016. Thyme and basil essential oils included in edible coatings as a natural preserving method of oilseed kernels. J. Sci. food Agric. 96, 183-191. https://doi.org/10.1002/jsfa. 7080

Sabaghi M, Maghsoudlou Y, Khomeiri M, Ziaiifar AM. 2015. Active edible coating from chitosan incorporating green tea extract as an antioxidant and antifungal on fresh walnut kernel. Postharvest Biol. Technol. 110, 224-228. https:// doi.org/10.1016/j.postharvbio.2015.08.025

Salcedo CL, López de Mishima B, Nazareno M. 2010. Walnuts and almonds as model systems of foods constituted by oxidisable, pro-oxidant and antioxidant factors. Food Res. Int. 43, 1187-1197. https://doi.org/10.1016/j. foodres.2010.02.016

Yousuf B, Qadri OS, Srivastava, AK. 2018. Recent developments in shelf-life extension of fresh-cut fruits and vegetables by application of different edible coatings: A review. $L W T$ Food Sci. Technol. 89, 198-209. https://doi.org/10.1016/j. lwt.2017.10.051

Zwarts L, Savage G, McNeil DL. 1999. Fatty acid content of New Zealand-grown walnuts (Juglans regia L.). Int. J. Food Sci. Technol. 50, 189-194. http://informahealthcare.com/ doi/abs/10.1080/096374899101229 